\title{
PRODUCTIVE PERFORMANCE AND PHYSIOLOGICAL PARAMETERS OF GROWING RABBITS AS AFFECTED BY WEANING AGE
}

\author{
W. H. Kishk
}

Department of Animal Production, Faculty of Agriculture, Suez Canal University, Ismailia, Egypt

\section{SUMMARY}

Main big problems which face meat production in commercial rabbit breeds are high mortality rate after weaning and decreased growth rate during fattening period of broiler rabbits. The purpose of this study was to evaluate the doe-offspring relationship through prolongation of weaning period on growth rate parameters and mortality percentages during high growth rate period (first 10 weeks of age in rabbits). A total of 150 of growing bunnies rabbit of New Zealand White rabbit were divided into two groups. The first group was weaned at 35 days of age (control group).While, the second group was weaned at 60 days of age. Growth rate measurements, mortality rate, blood metabolites levels and marketing weight at 10 weeks of age were determined. Blood samples were collected to assay blood metabolites levels of total protein, total lipids, glucose, creatinine and urea nitrogen during experimental period in blood serum samples. Data showed that there were significant differences $(P<0.05)$ between the two groups in most of the studied traits. Where, weaning at 60 days of age enabled growing rabbit pups to reach a higher body weight at marketing age (10 weeks). Marketing body weight averaged $1.845 \pm 0.48(\mathrm{Kg})$ and $1.650 \pm 0.35 \mathrm{Kg}$ for delayed weaning and control group, respectively. It could be concluded that weaning at 60 days of age is better to get a higher marketing weights and high economic efficiency values for rabbit meat production especially under extensive and semi-intensive rabbit breeding programs.

Keywords: rabbit bunnies, growth rate, marketing weight, blood metabolites, mortality rate

\section{INTRODUCTION}

In mammals, individual variation in important adaptive characters of offspring depends on the maternal ability in view of the high correlation of the maternal and offspring physiological systems (Mousseau and Fox, 1998). In mammals, milk is the most essential resource for offspring growth and survival (Forsyth and Hayden 1977; Jameson 1998). The average litter size in rabbits is about 4 to10. The pups need to be weaned in most commercial rabbitry after 1 month of their delivery. The new-born pups have little hair and they are deaf and blind for several days. After delivery, the mother rabbit returns to the nest once a day and nurses her pups. The nursing took place in the early morning and lasts for 2.7-4.5 min (Zarrow et al., 1965 and Hudson and Distel 1982; 1989). The young rabbits start to take a solid food at about 20 days after birth. They can move at 4 weeks of age and leave their nest. At that time of 35 to 40 days after delivery, they start weaning, but they continue to suckle for some

Issued by The Egyptian Society of Animal Production 
more weeks. The mother rabbits have maximum milk production 2 weeks after delivery. After weaning, lactation continues for an additional 2-4 weeks. At 8 weeks of age the young consume solid food. For laboratory rabbits, weaning and separation from the mother can be achieved at 6-7 weeks of age (Hagen 1974 and Hudson et al., 1996 and Martínez-Gómez et al., 2004). Many investigators have suggested that much of the interspecific variability in growth rates is due to differences in physiological constraints upon growth (Case 1978). The newborn, whether premature or mature, is able to digest monosaccharides and disaccharides, and protein, with little difficulty. Fats are less readily absorbed, although all infants have fat-splitting enzymes present in the gut (Llewellyn-Jones 1982). Rabbits have been reared for several reasons; one of them is meat production. Selection for growth rate is currently practiced in commercial sire lines of genetic schemes for rabbit improvement (Baselga and Blasco, 1989 and Lebas et al., 1996). One of the most serious management problems is the digestive trouble observed after weaning. This problem could be a consequence of a disturbance in the digestive system development due to inadapted composition of the diet ingested before weaning (Gidenne, 1997). Boriello and Carman (1983) showed that degradation of a high quality starch in the caecum favoured pathogenic flora. Moreover, feeding rabbits a high starch diet before weaning altered their viability after weaning (Lebas and Maitre, 1989). Increasing weaning age seemed to reduce both the stress in litters caused by separation from their dams and time required to achieve suitable food consumption levels (Xiccato et al., 2003).

The objectives of this work were to evaluate effects of lactation period prolongation on marketing weight, growth rate, mortality rate, food consumption and blood metabolites of growing rabbit bunnies.

\section{MATERIALS AND METHODS}

Hundred fifty newborn White New Zealand rabbit pups were allocated into two groups. The first group was weaned at traditional weaning age up to 35 days. While the second group, was weaned up to 60 days of age. Growth rate was measured through weekly live weight (LW) and finally after 10 weeks of age at marketing weight. Mortality rate from birth until marketing age, blood metabolites levels of blood serum of total protein, total lipids, blood sugar, creatinine and urea-nitrogen content during the experimental period (September and October, 2008) were quantified using colorimetric assay kits following the methodology as recommended by the producers. All does were kept at Experimental Farm of Faculty of Agriculture, Ismailia, Egypt in a semi-closed rabbitry. Rhythm of rabbit production is semi-closed in which number of litters for each doe was not less than 6 litters per year. Also, the doe was not exposed to natural mating before two weeks of kindling. All does have sexual rest during hot summer period to avoid the negative effects of high temperature on pregnancy rate and persistency. Housing conditions were semi-closed rabbitry provided with heavy curtains to avoid direct sun light during day time period. In addition, there were two large vacuum-fans to eliminate undesirable gases (ammonia and carbon dioxide). Each doe was reared in a galvanized cage $(70 \times 60 \mathrm{x}$ $45)$ connected to a nest box $(35 \times 30 \times 45)$, feeder and a clean water nipple. Lighting system was standardized to be $16 \mathrm{hr}$ per day. Multiparous does $(n=25)$ were selected in this experiment to produce 6 bunnies on average for each litter. Blood samples 
were collected every two weeks at 8:00 am and centrifuged at $3500 \mathrm{rpm}$ for 15 minutes. Blood serum was separated and stored at $-20{ }^{\circ} \mathrm{C}$ until the chemical analysis was executed. In the first group (normal weaning, NW) does reared their young kids in the traditional manner until they were weaned at 35 days of age. While, in the second group (delayed weaning, DW), does reared young kids until they were weaned at 60 days of age. In the two groups, both young rabbits and does were fed commercial pelleted feed rations ad libitum. The ration contained $16.8 \%$ crude protein, $2.9 \%$ crude fat, $14.1 \%$ crude fiber with a digestible energy of $10.3 \mathrm{DE}$ $\mathrm{MJ} / \mathrm{kg}$. The rabbits had free access to drinking fresh water from automatic nipples. Statistical analyses was performed for the experimental data by means of one-way analysis of variance (ANOVA-test), according to SPSS 8.0, (1997) software for the effect of weaning age on growth rate, marketing weight, mortality rate, blood metabolites levels. Duncan's multiple range test (1955) was used to test the significance of differences between different means of studied the parameters. In addition, the economic efficiency values were calculated for broiler rabbits at the end of fattening period (10weeks) taking into consideration prices of one $\mathrm{Kg}$ of live body weight of broiler rabbit and commercial ration at the time of the experiment according to formula cited by Meshreky et al. (2005) where, feed conversion equals feed consumed (grams) per growing broiler rabbit /average daily gain (grams) and feeding costs per $1 \mathrm{Kg}$ live body weight equals feed conversion $\times$ price of $1 \mathrm{Kg}$ consumed feedstuff. Meanwhile, the profitability (\%) equals price of $1 \mathrm{Kg}$ live body weight - costs of producing $1 \mathrm{Kg}$ live body weight/ Costs of producing $1 \mathrm{Kg}$ live body weight $\times 100$.

\section{RESULTS AND DISCUSSION}

The effects of weaning age on litter performance are presented in Table 1. Body weight did not differ significantly $(\mathrm{P}<0.05)$ between the two groups especially after $3^{\text {rd }}$ and $5^{\text {th }}$ week of age. Live body weights were 569 and $582 \mathrm{~g}$ for normal and delayed weaning, respectively at the $5^{\text {th }}$ week of age. While, significant differences began from the $7^{\text {th }}$ week of age in both groups. Body weight average was 1.101 and $1.200 \mathrm{Kg}$ for normal and delayed weaning groups at the $7^{\text {th }}$ week of age, respectively. Moreover, marketing body weight averaged $1.650 \pm 0.35 \mathrm{Kg}$ and $1.845 \pm 0.48 \mathrm{Kg}$ for normal and delayed weaning and they differed significantly $(\mathrm{P}<0.05)$. These results are go along with Xiccato et al. (2003), where they found delayed weaning is better than normal or early weaning avoiding weaning shock. Rabbit bunnies can move from liquid feeding to solid feeding gradually along a suitable period instead of a condensed or short period. This long period enabled full development for caecum without occurrence of digestive disorders. The main digestive disorder is diarrhea which leads to body weight loss and incomplete availability and digestibility of ingested food. Caecum plays a key role in fiber digestion in growing rabbits and caecal activity is very important to determine age of weaning in rabbits. In the present study, growth rate across different weeks of young rabbit ages, as shown in Table (1), was better and differed significantly $(\mathrm{P}<0.05)$ in the second group DW from the first group NW especially at the $7^{\text {th }}, 8^{\text {th }}$ and $10^{\text {th }}$ week of ages. This is may be due to that growing rabbits in the second group DW do not face sudden movement from liquid feeding to solid feeding. This sudden movement can cause a high activation rate of pathogenic bacteria especially in digestive tract which lead to high mortality rate during this period as shown in Table (1). Where, mortality rates 
reached $7 \%, 10 \%$ and $15 \%$ for normal weaning whereas it reached $6 \%, 8 \%$ and $11 \%$ for delayed weaning at the $7^{\text {th }}, 8^{\text {th }}$ and $10^{\text {th }}$ week of age, respectively. These mortality rates differed significantly $(\mathrm{P}<0.05)$ between the two groups (Table 1). Low mortality rate in DW can explain high efficiency of digestive tract in digestion and absorption of ingested food. This efficiency reflects the high live body weight and high body weight gain in addition to the normal body development which leads finally to decrease mortality rate at marketing age (10 weeks) as shown in Table (1).

Table 1. Performance of White New Zealand growing rabbits during the weaning period from birth until weaning and during the growth period from weaning up to 10 weeks of age (Means \pm SE)

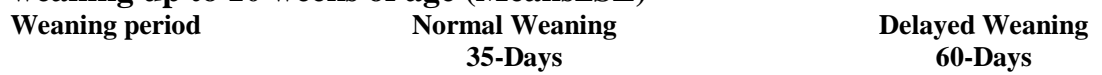

Generally, the economic costs of animal products depend on many factors. Some of these factors are feed conversion, feeding costs, achieved mortality rates and growth rates. The increase of nutritional costs could result in increasing the price of end product of rabbit meat production and consequently it could reduce profit margin (Table 2). Opposite to that, the increase in growth rate could result in reducing the required time to reach marketing weight for meat production and finally could result in reducing production costs as pointed out for delayed weaning age at 60 days. This experiment shows the economic value of obtained results especially for effect of delaying weaning on reducing mortality rate and enhancement of growth (Table 1). Feeding costs and profitability \% differed significantly $(\mathrm{P}<0.05)$ between two the groups (Table 2).

Table 2. The economic efficiency values of growing broiler rabbits as affected by weaning age

\begin{tabular}{lccc}
\hline Weaning age & Feed conversion & Nutritional costs* & Profitability (\%) \\
\hline 60-Days & $5.52 \mathrm{~A}$ & $9.94 \mathrm{~A}$ & $111.27 \mathrm{~A}$ \\
35-Days & $6.21 \mathrm{~B}$ & $11.18 \mathrm{~B}$ & $87.84 \mathrm{~B}$ \\
\hline
\end{tabular}

${ }^{\mathrm{A}, \mathrm{B}}$ Mean with different letters between two groups, differ significantly $(\mathrm{P}<0.05)$.

*(LE)/ $1 \mathrm{Kg}$ live body weight. 
Blood metabolites levels in both groups differed significantly $(\mathrm{P}<0.05)$ in $r$ total protein and blood-urea which indicate the better digestibility and usage of protein content by the second group than first group of normal weaning ( Table 3). This can explain the high growth rate of second group compared to first one at 35 days of age. Some blood aspects in normal range, are highly correlated with growth performance as shown in Table 4 . Where, most studied blood metabolites correlated positively with body weight and feed intake except total lipids as presented in Table 4. Such basic information is available for proper managerial approaches towards improvement of growth performance (Ashour, 2001). Meshreky et al. (2005) found that, Hematocrit \%, hemoglobin concentration, plasma total proteins, globulin and albumin levels increased by advancing of rabbit age (from 12 to 16 weeks), however, levels of glucose, total lipids and cholesterol decreased. These results agree with the findings of Chiericato et al. (2000) and Meshreky et al. (2002). Ashour (2001) attributed the decrease of cholesterol to the higher utilization of cholesterol for energy metabolism and synthesis of sexual steroids. In addition, effects of weaning period on weight gain, feed intake (Table 1), weight gain / feed $(\mathrm{g} / \mathrm{Kg}$ ) and mortality rate percent during 10 weeks of age are presented in Table, 1. It is obvious to get better results from delayed weaning for weight gain, feed intake, weight gain/feed intake and mortality \%. Both weight gain/feed intake and mortality $\%$ differed significantly $(\mathrm{P}<0.05)$ between the two groups of weaning age as shown in Table 1.

Table3. Means $\pm \mathrm{SE}$ of blood serum metabolites of growing White New Zealand rabbits during weaning period and up to marketing age (10- weeks)

\begin{tabular}{|c|c|c|c|c|c|c|c|c|c|c|}
\hline \multirow{3}{*}{$\begin{array}{l}\text { Blood } \\
\text { Metabolites }\end{array}$} & \multirow{2}{*}{\multicolumn{5}{|c|}{$\begin{array}{c}\text { Normal Weaning } \\
\text { At } 5 \text { weeks }\end{array}$}} & \multicolumn{5}{|c|}{ Delayed Weaning } \\
\hline & & & & & & & & At 8 wee & ks & \\
\hline & $3^{\text {rd }}$ & $5^{\text {th }}$ & $7^{\text {th }} \quad \varepsilon$ & $8^{\text {th }}$ & $10^{\text {th }}$ & $3^{\text {rd }}$ & $5^{\text {th }}$ & $7^{\text {th }}$ & $8^{\text {th }}$ & $10^{\text {th }}$ \\
\hline \multirow{2}{*}{$\begin{array}{l}\text { Total } \\
\text { Protein } \\
(\mathrm{g} / \mathrm{dl})\end{array}$} & 4.12 & 4.4 & 4.6 & $5.15^{\mathrm{A}}$ & $5.55^{\mathrm{A}}$ & 4.26 & 4.45 & 4.72 & $6.35^{\mathrm{B}}$ & $6.61^{B}$ \\
\hline & 0.22 & 0.39 & 0.31 & 0.28 & 0.29 & 0.25 & 0.34 & 0.39 & .27 & 0.21 \\
\hline \multirow{2}{*}{$\begin{array}{l}\text { Total } \\
\text { Lipids } \\
\text { (mg/dl) }\end{array}$} & 350 & 342 & 339 & 320 & 310 & 342 & 321 & 330 & 327 & 301 \\
\hline & 5.33 & 4.41 & 6.61 & 5.28 & 6.31 & 4.51 & 5.26 & 4.68 & 6.87 & 5.73 \\
\hline \multirow{2}{*}{$\begin{array}{l}\text { Creatinine } \\
(\mathrm{mg} / \mathrm{dl})\end{array}$} & 1.1 & 1.3 & 1.4 & 1.44 & 1.34 & 1.2 & 1.35 & 1.46 & 1.56 & 1.48 \\
\hline & 0.07 & 0.04 & 0.06 & 0.07 & .09 & 0.06 & 0.03 & 0.04 & 0.06 & 0.08 \\
\hline \multirow{2}{*}{$\begin{array}{l}\text { Urea-N } \\
\text { (mg/dl) }\end{array}$} & 13.2 & 13.6 & 14.45 & \multicolumn{2}{|c|}{$15.0^{\mathrm{A}} 17.5^{\mathrm{A}}$} & 14.32 & 15.6 & 14.86 & \multicolumn{2}{|c|}{$17.2^{\mathrm{B}} 19.66^{\mathrm{B}}$} \\
\hline & 0.45 & 0.39 & 0.55 & 0.62 & 0.81 & 0.33 & 0.47 & 0.41 & 0.59 & 0.74 \\
\hline Blood & 241 & 250 & 260 & 265 & 260.5 & 235 & 240 & 266 & 277 & 271 \\
\hline $\begin{array}{l}\text { Glucose } \\
(\mathrm{mg} / \mathrm{dl})\end{array}$ & 4.61 & 7.85 & 5.66 & 8.52 & 6.68 & 5.28 & 6.39 & 4.49 & 7.29 & 6.27 \\
\hline
\end{tabular}


It could be concluded that delayed weaning (60-days) could be recommended as a good tool to avoid early weaning problems and to increase economic efficiency values which related to weaning at 60 days of age. Delayed weaning can improve growth rate, average weight gain / feed intake $(\mathrm{g} / \mathrm{Kg})$ and subsequently can increase marketing weight at 10 weeks as pointed out from this experiment

Table 4. Correlation coefficients ( $r$ ) between growth performance and blood serum metabolites of growing White New Zealand rabbits during lactation period and up to marketing age (10- weeks)

\begin{tabular}{|c|c|c|c|c|c|c|c|c|}
\hline $\mathrm{r}$ & BW & WG & FI & GL & TL & TP & $\mathrm{Cr}$ & Ur \\
\hline BW & $\begin{array}{l}1.00 \\
0\end{array}$ & $-0.25 \mathrm{~ns}$ & $0.97 * * *$ & $0.90 * * *$ & $-0.82 * * *$ & $0.89 * * *$ & $0.79 * * *$ & 0.83 *** \\
\hline WG & & 1.00 & $0.97 * * *$ & $-0.26 \mathrm{~ns}$ & $0.53 \mathrm{~ns}$ & $-0.59 \mathrm{~ns}$ & $0.02 \mathrm{~ns}$ & $-0.63^{*}$ \\
\hline FI & & & 1.00 & $0.84 * * *$ & $-0.87 * * *$ & $0.84 * * *$ & $0.78 * * *$ & $0.83^{* * *}$ \\
\hline GL & & & & 1.00 & $-0.09 \mathrm{~ns}$ & $0.82 * * *$ & $0.88 * * *$ & $0.63 *$ \\
\hline TL & & & & & 1.00 & $-.78 * * *$ & $-0.62 \mathrm{~ns}$ & $-0.90 * * *$ \\
\hline $\mathrm{TP}$ & & & & & & 1.00 & $0.74 * *$ & $0.92 * * *$ \\
\hline $\mathrm{Cr}$ & & & & & & & 1.00 & $0.63 *$ \\
\hline $\mathrm{Ur}$ & & & & & & & & 1.00 \\
\hline
\end{tabular}

\section{REFERENCES}

Ashour, G., 2001. Blood metabolites, minerals and hormones in relation to growth of rabbits. Egyptian J. Rabbit Science, 11: 73-91.

Baselga, M. and A. Blasco, 1989. Mejora genética del conejo de producción de carne. Mundi- Prensa, p 110.

Boriello, S. P. and R. J. Carman, 1983. Association of iota-like toxin and clostridium spiroforme with both spontaneous and antibiotic-associated diarrhea and colitis in rabbits. J. Clin. Micro. 17: 414-418.

Case, T. J. 1978. On the evolution and adaptive significant of postnatal growth rates in the terrestrial vertebrates. The Quarterly Review of Biology, 53: pp.243-282.

Chiericato, G. M., C. Rizzi, L. Ravarotto, and H. Zakaria, 2000. Circulating levels of metabolites, enzymes and minerals of Grimaud female rabbits from weaning to 120 days of age. $7^{\text {th }}$ World Rabbit Congress, Valencia, Spain, (4-7 July), pp. 111116.

Duncan, D.B. 1955. Multiple range and multiple " F " Test. Biometrics, $11: 1-42$.

Forsyth I.A, Hayden T.J (1977). Comparative endocrinology of mammary growth and lactation. Symp Zool Soc Lond 41:135-163.

Gidenne, T. 1997. Caeco-colic digestion in the growing rabbit: impact of nutritional factors and related disturbances. Livest. Prod. Sci., 51: 73-88.

Hagen, K.W.1974. Colony husbandry. In "The Biology of the Laboratory Rabbit", Academic Press, New York, PP: 23-47.

Hudson, R., Á. Bilkó, and V. Altbäcker, 1996. Nursing, weaning and the development of independent feeding in the rabbit (Oryctolagus cuniculus). Z Säugetierkde 61:39-48 
Hudson, R and H. Distel, 1982. The pattern of behaviour of rabbit pups in the nest. Behaviour

Hudson, R. and H. Distel, 1989. Temporal pattern of suckling in rabbit pups: a model of circadian synchrony between mother and young. In: Reppert SM (ed) Development of circadian rhythmicity and photoperiodism in mammals. Perinatology Press, Boston, pp 83-102

Jameson, E. W. 1998. Prepartum mamogenesis, milk production, and optimal litter size. Oecologia 114:288-291

Lebas, F. and I. Maitre, 1989. Alimenation de preservage. Cuniculture 16: 135-140.

Lebas, F., P. Coudert, H. Rochambeau, and R. G. Thébault, 1996. Le Lapin. Elevage et Pathologie. FAO, Rome, Italy.

Llewellyn-Jones, D. 1982. Fundamentals of Obstetrics and Gynaecology. $3^{\text {rd }}$ Ed., Pub. ELBS \& Faber and Faber Limited, UK, PP:435-464.

Martínez-Gómez, M., M. Juárez, H. Distel, and R. Hudson. 2004. Overlapping litters and reproductive performance in the domestic rabbit. Physiol Behav 82:629-636.

Meshreky, S. Z., N. A. Ashmawy, A. M. Elkiaty, and S. A. Z. Gad Alla, 2002. Effect of vitamin $\mathrm{E}$ and /or selenium injection on growth performance and some blood constituents of New Zealand White and Baladi Black rabbits weaned during summer season of middle Egypt. $3^{\text {rd }}$ Sci. Con. On Rabbits Production in Hot Climates, 8-11 Oct, pp: 165-181.

Meshreky, S. Z., S. A. Gad Alla, and M. M. Arafa, 2005. Growth performance , carcass traits, physiological response and economical efficiency of Baladi Red, VLine rabbits and their cross-under Egyptian environmental conditions. The $4^{\text {th }}$ Inter. Con. on Rabbit Prod. in Hot Clim., Sharm El-Sheikh, Egypt,pp:197-210 (2005).

Mousseau, T.A. and C. W. Fox, 1998. The Adaptive Significance of Maternal Effects, Trends Ecol. Evol., 1998, vol. 13, pp. 403-407.

SPSS for Windows, (1997). Version 8.0, Copyright SPSS Inc.

Xiccato, G., A. Trocino, A. Sartori, and P. I. Queaque, 2003. Effect of weaning diet and weaning age on growth, body composition and caecal fermentation of young rabbits. Anim. Sci., 77: pp: 101-111.

Zarrow, M. X., V. H. Denenberg, and C. O. Anderson, 1965. Rabbit: Frequency of suckling in the pup. Science 150: 1835-1836. 
الأداء الإتتاجى والمقاييس الفسيولوجية للأرانب النامية المتأثرة بعمر الفطام

وليد حسين كثك

قسم الإتتاج الحيواني، كلية الزراعة، جامعة قناة السويس، ب r ه 1 ؛ الإسماعيلية، جمهورية مصر العربية

إن من أكبر المشكلات التى تواجهة إنتاج اللحوم من سلالات الأرانب التجارية هى إرتفاع نسبة النفوق بعد

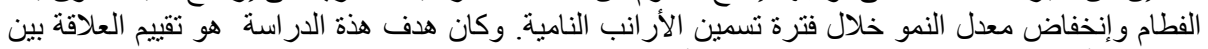

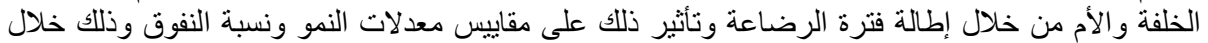

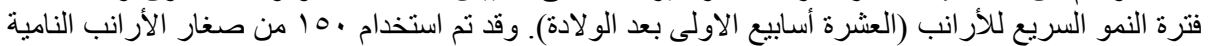

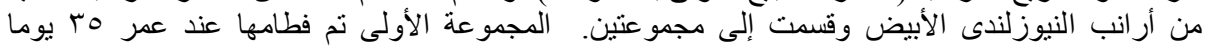

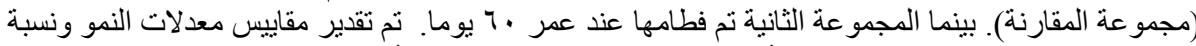

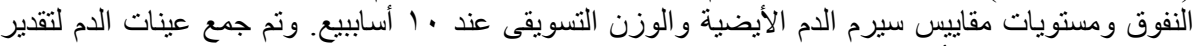

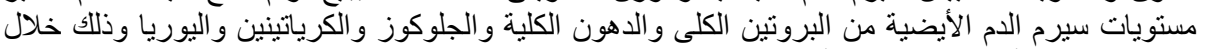

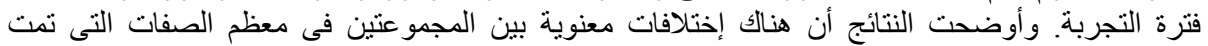

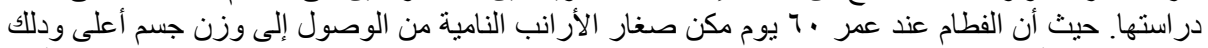

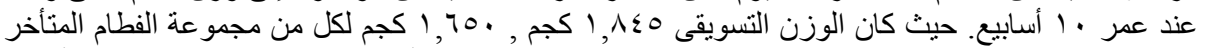

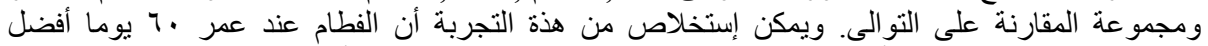
للحصول على وزن تسويقى أعلى وكفاءة إقتصادية عالية ودللك لإنتاج لحوم الأرانب تحت نظم التربية المكئفة و الثبهة مكثفة. 